\title{
塔里木盆地中央隆起带中、西段及邻区中、 下寒武统盐相关构造及其变形机理
} \author{
赵㻇 ${ }^{(1)}$ ，陈书平 ${ }^{1}$ \\ (1) 油气资源与探测国家重点实验室, 北京 102249 ; \\ (2) 中国石油大学盆地与油藏研究中心, 北京 102249 ; \\ (3) 中国石化西北油田分公司, 乌鲁木齐 830011; \\ (4) 国土资源部油气资源战略研究中心, 北京 100034 \\ *E-mail: tanglj@cup.edu.cn
}

汤良杰 ${ }^{(1) *}$ ，黄太柱 ${ }^{(3)}$, 邱海峻 ${ }^{(4)}$, 漆立新 ${ }^{(3)}$, 杨勇 ${ }^{(1)}$ (2) 谢大庆 ${ }^{(3)}$, 余一欣 ${ }^{(1)}$,

收稿日期: 2011-12-15; 接受日期: 2012-04-05

国家自然科学基金(批准号：41172125，40972090，40802030，40672143 和 40472107)、国家重点基础研究发展计划(编号：2012CB214804, 2005CB422107 和 G1999043305)、全国油气资源战略选区调查与评价专项(编号: 2009GYXQ02-05)、教育部博士点基金(编号: 200804250001) 和国家科技重大专项(编号: 2011ZX05002-003-001HZ)资助

\begin{abstract}
摘要＼cjkstart塔里木盆地中央隆起带中、西段及邻区中、下寒武统广泛发育盐岩层系. 本文 通过地震和钻井资料综合解释和分析，发现这套盐岩层系形成时代老，埋藏深度大，流 动聚集幅度较小，厚度分布不均匀，它们作为区域滑脱层对该区盐上古生界构造变形起 着重要控制作用, 形成一系列含油气圈闭构造. 同时, 由于寒武系盐岩层系提供的优质 盖层和封闭条件, 大大提升了该区盐下震旦-寒武系目的层系的油气勘探价值. 研究表 明，该区中、下寒武统盐相关构造主要包括盐枕构造、盐滚构造、盐(上)背斜构造、盐 刺穿构造、盐拱-盐上断块构造组合、基底断裂-盐背斜构造组合、基底断块-盐丘构造组 合、盐岩滑脱-断层相关擢鲏组合、基底断块-盐拱-盐上叠瓦冲断组合. 这些盐相关构造 的形成演化和变形机理主要受控于基底断裂作用、挤压缩短作用、塑性流动聚集作 用、上覆层系重力作用和盐上层断裂滑脱作用等, 盐相关构造主要沿基底断裂或断块构 造带成排成带分布.
\end{abstract}

关键词

盐相关构造

中、下寒武统

变形机理

中央隆起带中、西段

塔里木盆地
塔里木盆地中央隆起带油气勘探近年来取得了 重大进展，找到了塔中 I 号富油气构造带，在巴楚隆 起和麦盖提斜坡也找到了油气田(藏), 展示了该区巨 大的油气勘探潜力 ${ }^{[1 \sim 5]}$. 对塔里木盆地中央隆起带 中、西段构造特征已开展过大量研究工作, 提出了克
拉通内古隆起的重要认识 ${ }^{[4,6]}$, 总结了塔中隆起和巴 楚隆起的断裂构造模式和展布规律，提出该区构造变 形样式复杂, 发育多种类型的逆冲断层、反冲断层和 走滑断层等 ${ }^{[799]}$, 明确了塔中隆起和巴楚隆起在变形 时代、构造样式、构造演化和成因机理上的差异性 ${ }^{[8 ~ 14]}$,

中文引用格式: 汤良杰, 黄太柱, 邱海峻, 等. 塔里木盆地中央隆起带中、西段及邻区中、下寒武统盐相关构造及其变形机理. 中国科学: 地球科学, 2013, 43: 33-43

英文引用格式: Tang L J, Huang T Z, Qiu H J, et al. Salt-related structure and deformation mechanism of the Middle-Lower Cambrian in the middle-west parts of the Central Uplift and adjacent areas of the Tarim Basin. Science China: Earth Sciences, 2012, 55: 1123-1133, doi: 10.1007/s11430-012-4414-3 
探讨了构造特征与油气成藏和油气远景的关系 ${ }^{[4-5,14]}$. 地震和钻探成果已经证实, 塔里木盆地中央隆 起带中、西段及邻区中、下寒武统广泛发育盐岩层系, 它们作为区域滑脱层对该区盐上古生界构造变形起 着重要控制作用, 形成一系列含油气圈闭构造 ${ }^{[15 ~ 17]}$. 同时, 由于寒武系盐岩层系提供的优质盖层和封闭 条件, 大大提升了该区盐下震旦-寒武系目的层系的 油气勘探价值.

近年来, 伸展环境和挤压环境含油气盆地(如墨 西哥湾、北海、波斯湾和塔里木盆地库车坳陷等)盐 构造研究取得了重大进展 ${ }^{[18 ~ 23]}$. 我国的一些大型含 油气盆地, 如塔里木、四川、江汉和渤海湾盆地等, 广 泛发育多期盐岩层系和多种类型的盐构造, 盐岩层 系形成时代涉及寒武系、石炭系、三叠系、古近系和 新近系. 已经对这些盆地的盐构造开展过研究并取 得进展, 包括渤海湾盆地新生代伸展环境下的盐构 造变形研究 ${ }^{[24,25]}$, 四川盆地中、下三叠统海相碳酸盐 岩层系中的盐相关构造变形研究 ${ }^{[26,27]}$, 江汉盆地的盐 构造变形研究 ${ }^{[28,29]}$, 塔里木盆地库车前陆褶皱-冲断带 挤压环境下的盐相关构造及其变形机理研究等 ${ }^{[30 \sim 35]}$. 资料表明, 国外盐构造研究大都针对被动陆缘盆地或 板块缝合带附近的前陆盆地, 盐岩层系规模和厚度 巨大, 盐岩流动性极强, 盐构造变形样式复杂多变. 而对于克拉通内古隆起背景下时代古老、厚度较薄的 盐层及其变形构造的研究相对较少, 这些形成早、厚 度薄的盐岩层系变形时的力学行为以及对其围岩变 形的控制作用, 涉及到特殊动力学背景条件下非常 规盐构造形成和演化的理论模式. 尽管塔里木盆地
中央隆起带中、西段及邻区已开展大量研究工作并取 得丰硕成果, 但该区盐相关构造研究仍是薄弱环节. 本文试图通过地震剖面解释和钻井资料分析, 对下 述问题做一探讨: 1) 时代为早、中寒武世的古老盐岩 层系变形样式；2）深层盐相关构造分布模式；3）克 拉通内古隆起不均匀展布的薄层盐岩层系变形的运 动学模式；4) 不同于库车和川东北前陆挤压环境的 克拉通内古隆起盐构造及其相关构造的变形机理.

\section{1 塔里木盆地中央隆起带中、西段及邻区 构造-层序组合划分及主要特征}

塔里木盆地中央隆起带中、西段及邻区，位于塔 里木盆地中部地区，包括塔中隆起、巴楚隆起及相邻 的麦盖提斜坡、塘古巴斯坳陷和顺托果勒隆起等地区 (图 1), 该区构造变形复杂, 经历了长期构造演化, 构 成了横亘塔里木盆地中部、以不同时代大型古隆起为 特征的巨型构造带.

以中、下寒武统盐岩层系为界, 可以将塔里木盆 地中央隆起带中、西段及邻区划分为 3 个大的构造地层层序组合(图 2).

\section{1 盐下构造-地层层序组合}

由震旦系和下寒武统组成, 属于一套海相碳酸 盐岩和碎屑岩层系为主的沉积, 简述如下: 下震旦统 在该区分布较局限，可能仅分布在中央隆起带中、西 段北翼地区，主要为一套海相碎屑岩、碳酸盐岩和火 山碎屑岩建造; 上震旦统沉积广泛, 为一套台地相碳

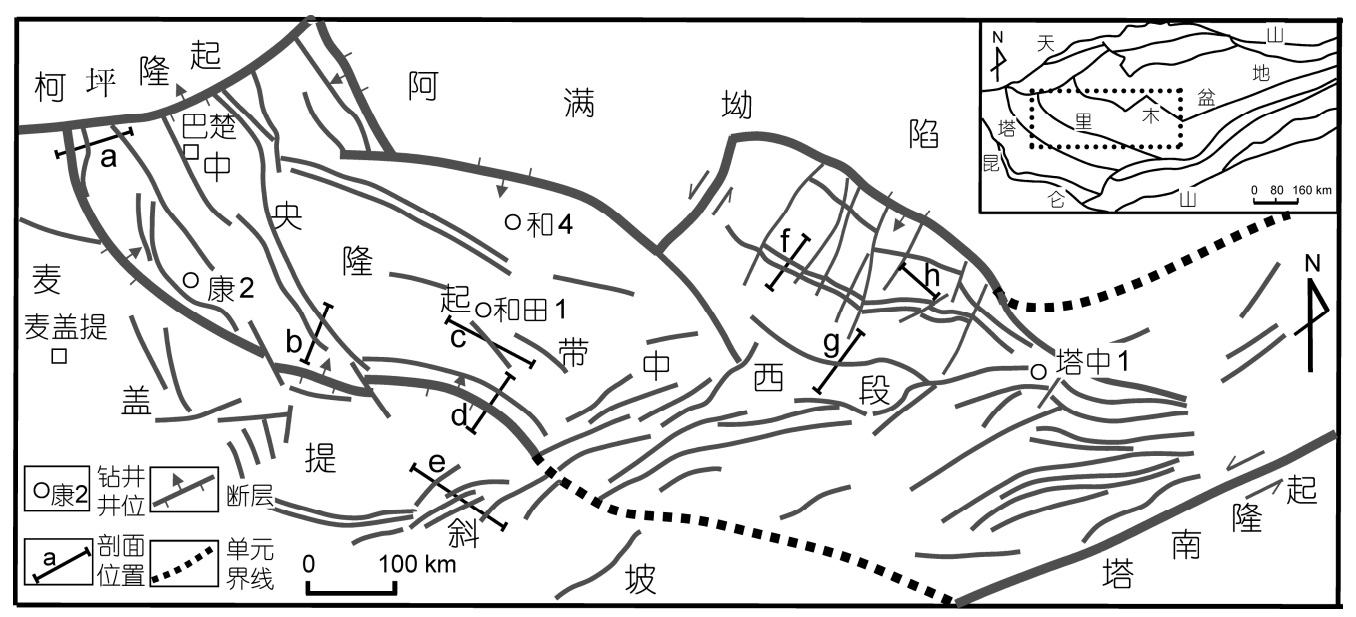

图 1 塔里木盆地中央隆起带中、西段构造位置略图 


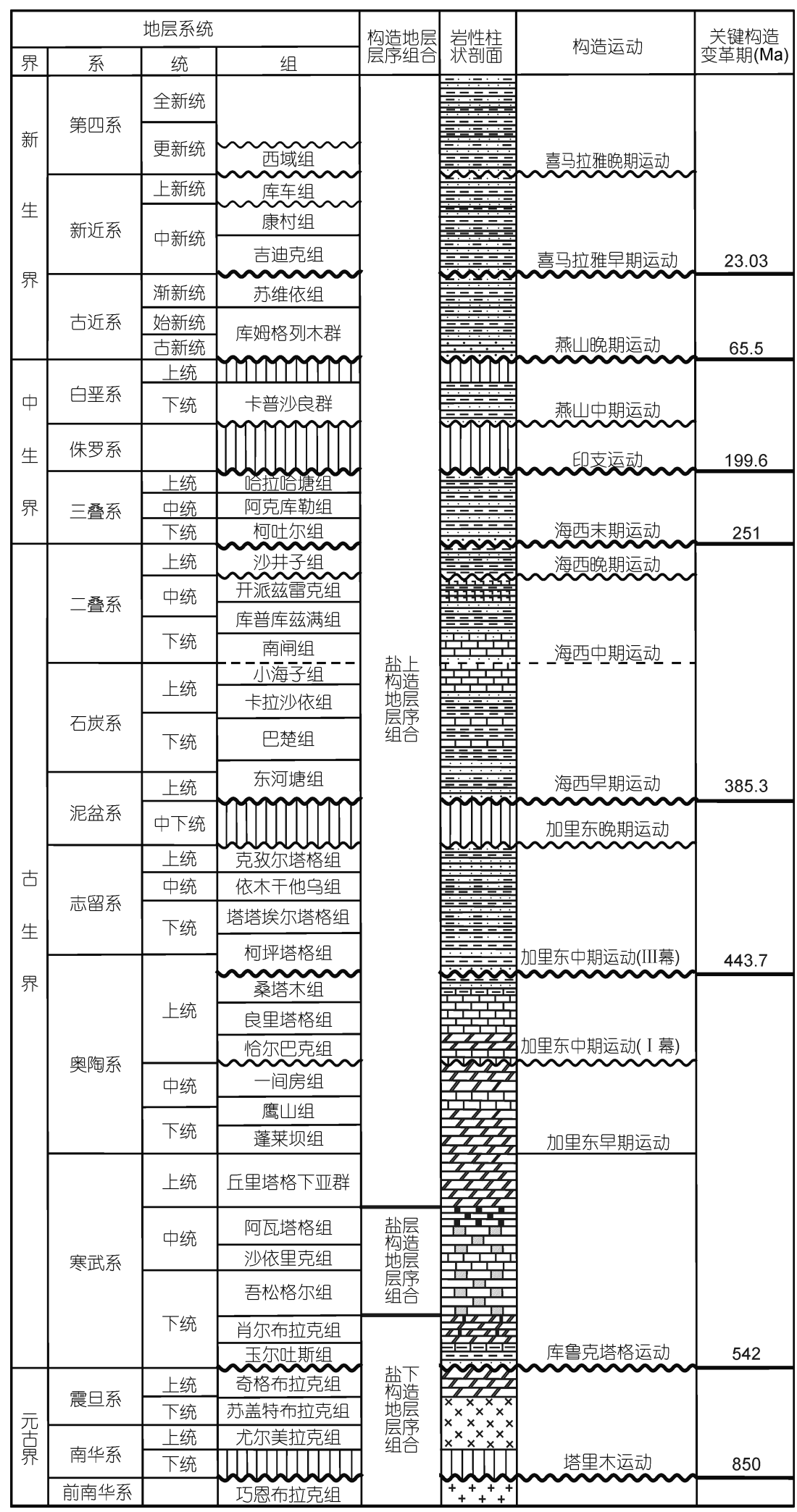

图 2 塔里木盆地中央隆起带中、西段及邻区构造-地层层序组合 
酸盐岩沉积, 厚约 500 800 m, 角度不整合在南华系 或基底变质岩系之上; 下寒武统中、下部玉尔吐斯组 和肖尔布拉克为一套开阔台地相碳酸盐岩沉积, 岩 性为灰色中-细晶白云岩夹藻白云岩、泥晶灰岩及钙 质泥岩.

\section{2 盐层构造-地层层序组合}

由下寒武统上部吾松格尔组和中寒武统沙依里 克组、阿瓦塔格组组成,一般可划分为 4 个岩性段: 1) 下部膏盐岩段：为中层-厚层状灰色膏盐岩、灰白色膏 岩、亳质云岩、泥质云岩、灰褐色云质膏岩夹褐灰色 云质泥岩；2）盐间灰岩段：主要为灰色泥晶灰岩夹 深灰色白云岩；3) 中部膏盐岩段: 为中-厚层状灰白 色膏岩、泥质膏岩、亳盐岩夹褐色膏质泥岩; 4) 上部 含膏云岩段: 深灰色含亳云岩、亳质泥岩为主夹灰色 白云岩和红褐色泥岩. 总体来看, 含盐层系沉积较稳 定, 分布广泛, 以膏岩、膏盐岩、膏质云岩、含膏泥 岩为主, 纯盐岩层系不发育. 与世界上其它含盐盆地 相比, 盐岩层系厚度较小, 钻井揭示厚度在 200 700 $\mathrm{m}$ 之间(表 1), 地震资料揭示厚度可达 $1200 \mathrm{~m}$ 以上, 流动聚集现象明显, 分布不均一性强, 是重要的区域 性滑脱层系. 盐岩层系埋藏深度大, 与全球大部分盐 构造研究区为伸展或挤压环境不同, 区域构造背景 环境为克拉通内古隆起, 含盐层系时代老、埋藏深、 厚度小. 盐岩层系埋藏深度自西向东逐渐加深, 最大 埋藏深度达到 $7000 \mathrm{~m}$ 以上. 盐岩层系主要通过塑性 流动变形来影响上覆层构造变形, 总体来看, 中央隆 起带中、西段及邻区盐岩层系塑性流动特征比较明显. 由于该区盐岩层系厚度偏小, 同时盐间云岩和灰岩 夹层分布较稳定, 因此在地震剖面上, 盐岩层系总体 仍然呈现出似层状反射特征, 但该层段同相轴明显 紊乱, 形成各种与盐岩层系塑性流动有关的透镜状、 丘状等比较杂乱的反射特征, 局部聚集增厚, 有规模 不太大的盐丘或盐背斜形成, 但较少形成盐刺穿构 造.

\section{3 盐上构造-地层层序组合}

盐上组合厚度巨大, 由上寒武统至第四系组成, 其中上寒武统和奥陶系为一套台地相灰色白云岩、灰 岩、泥灰岩和钻质泥岩等, 厚 $2500 \mathrm{~m}$ 以上; 志留-泥 盆系为海相陆源碎屑岩沉积, 厚达 $1300 \mathrm{~m}$ 以上; 石 炭-二叠系为海陆交互相碳酸盐岩、碎屑岩夹火山岩, 厚达 $3000 \mathrm{~m}$ 以上; 中生界为陆相碎屑岩建造, 发育 不全, 厚达 $1000 \mathrm{~m}$ 以上, 塔中隆起缺失侏罗系, 巴楚 隆起大部缺失三叠系、全部缺失侏罗系和白严系; 古 近系和新近系为陆相碎屑岩建造, 最厚达 $3000 \mathrm{~m}$ 以 上; 第四系为洪积、冲积和风积松散砂和砂砾堆积, 厚数十至数百米.

\section{2 塔里木盆地中央隆起带中、西段盐相关构 造样式}

塔里木盆地中央隆起带中、西段塔中、巴楚地区, 经历了多期差异构造变动, 塔中地区主要受加里东 中期、加里东晚期-海西早期构造运动的影响, 后期构 造改造逐渐减弱. 巴楚地区正好相反, 加里东和海西 早期运动与塔中相比明显要弱, 海西晚期岩浆活动 强烈, 中生代强烈隆升遭受剥蚀, 喜马拉雅期强烈逆 冲推覆和走滑位移. 对于深层中、下寒武统盐岩层系 来说, 其构造变形主要受挤压或走滑-挤压控制, 形 成了一系列盐相关构造样式.

\section{1 盐枕构造}

塔里木盆地中央隆起带中、西段及邻区寒武系盐 枕构造较为发育, 是中、下寒武统盐岩层系本身发生 流动聚集形成的“枕状”构造. 由于中、下寒武统盐岩 层系本身厚度较小, 形成的盐枕规模也较小, 幅度较 低, 形态表现为上凸下平. 盐岩层系局部聚集形成的 盐枕构造, 也影响到其上覆层系发生变形, 在盐枕构 造之上形成盐上背斜构造, 构造幅度由深层往浅层 逐渐变小(图 3).

表 1 钻井揭示中、下寒武统盐岩层系厚度表 ${ }^{\text {a) }}$

\begin{tabular}{|c|c|c|c|c|c|c|c|c|c|c|c|c|}
\hline \multirow[b]{2}{*}{$\begin{array}{l}\text { 地层 } \\
\text { 系统 }\end{array}$} & \multicolumn{2}{|c|}{$\begin{array}{c}\text { 同 } 1 \text { 井 } \\
\end{array}$} & \multicolumn{2}{|c|}{ 康 2 井 } & \multicolumn{2}{|c|}{ 方 1 井 } & \multicolumn{2}{|c|}{$\begin{array}{c}\text { 和 } 4 \text { 井 } \\
\end{array}$} & \multicolumn{2}{|c|}{ 和田 1 井 } & \multicolumn{2}{|c|}{$\begin{array}{c}\text { 中 } 4 \text { 井 } \\
\end{array}$} \\
\hline & $\begin{array}{c}\text { 底界深度 } \\
(\mathrm{m})\end{array}$ & $\begin{array}{c}\begin{array}{l}\text { 厚度 } \\
(\mathrm{m})\end{array} \\
\end{array}$ & $\begin{array}{c}\text { 底界深度 } \\
(\mathrm{m})\end{array}$ & $\begin{array}{c}\text { 厚度 } \\
(\mathrm{m})\end{array}$ & $\begin{array}{c}\text { 底界深度 } \\
(\mathrm{m})\end{array}$ & $\begin{array}{c}\text { 厚度 } \\
(\mathrm{m})\end{array}$ & $\begin{array}{c}\text { 底界深度 } \\
(\mathrm{m})\end{array}$ & $\begin{array}{c}\text { 厚度 } \\
(\mathrm{m})\end{array}$ & $\begin{array}{c}\text { 底界深度 } \\
(\mathrm{m})\end{array}$ & $\begin{array}{c}\text { 厚度 } \\
(\mathrm{m})\end{array}$ & $\begin{array}{c}\text { 底界深度 } \\
(\mathrm{m})\end{array}$ & $\begin{array}{c}\text { 厚度 } \\
(\mathrm{m})\end{array}$ \\
\hline 上寒武统 & 3944 & 881 & 4938 & 600 & 3833 & 868 & 5002 & 755 & 6161 & 639 & 6752 & 1224 \\
\hline $\begin{array}{c}\text { 中下寒武统 } \\
\text { 盐岩层系 }\end{array}$ & 4652 & 708 & $5634.5 \nabla$ & 696.5 & 4614 & 781 & 5903 & 563 & $6813.5 \nabla$ & 652.5 & $7220 \nabla$ & 468 \\
\hline
\end{tabular}

a) 据中国石化西北油田分公司资料简化修改. $\nabla$ 表示未钻穿 


\section{2 盐滚构造}

塔里木盆地中央隆起带中、西段及邻区中、下寒 武统盐岩层系发育的另一类盐构造是盐滚构造, 其 几何形态主要表现为盐岩层系底部平整或呈极平缓
的背斜形态，盐岩层系顶部的一侧与上覆地层呈整 一接触关系，另一侧呈断层接触关系，盐体本身呈现 为“三角”形态, 靠近断裂部位盐岩层系急剧增厚, 远 离断裂盐岩层系迅速减薄(图 4). 在断裂下盘的盐滚

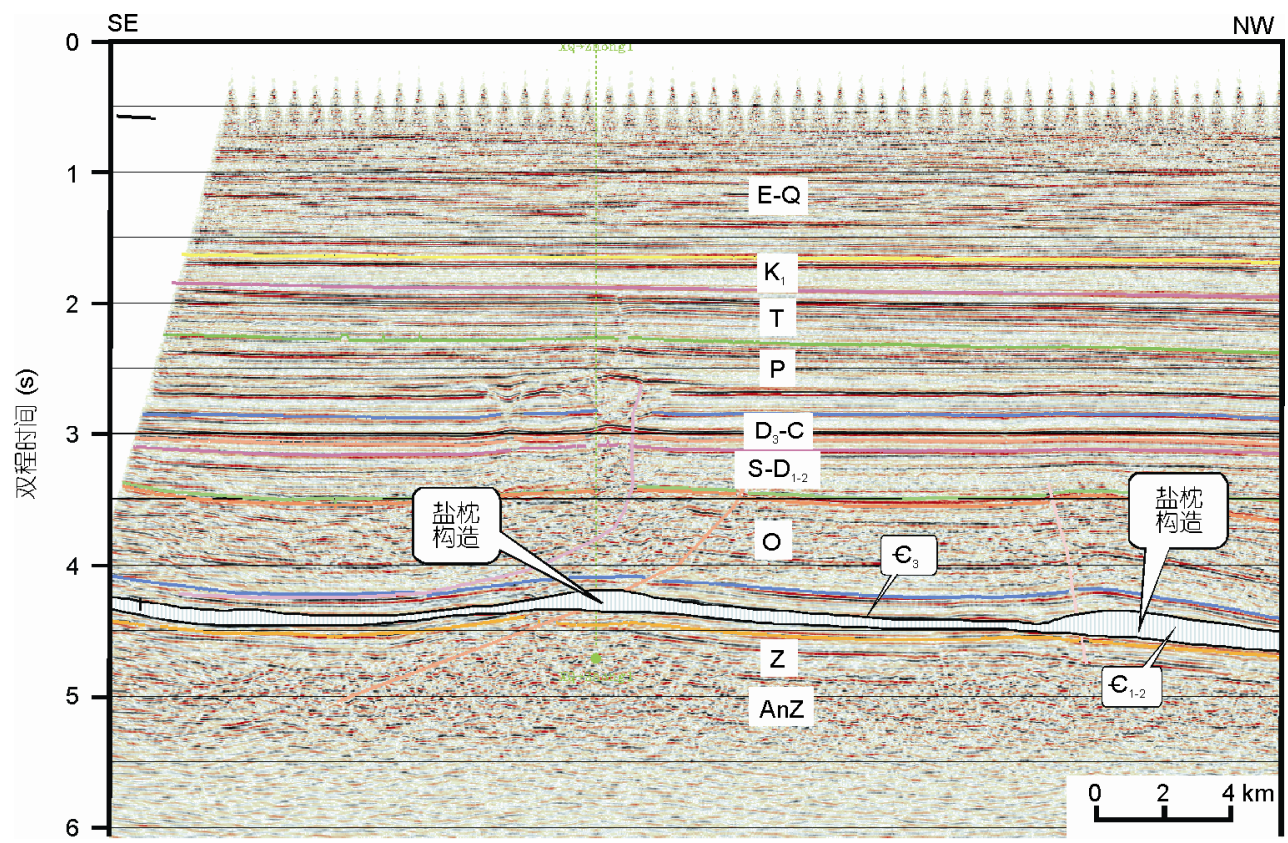

图 3 盐枕构造

据 TZL1312 地震剖面解释, 剖面位置见图 1-h

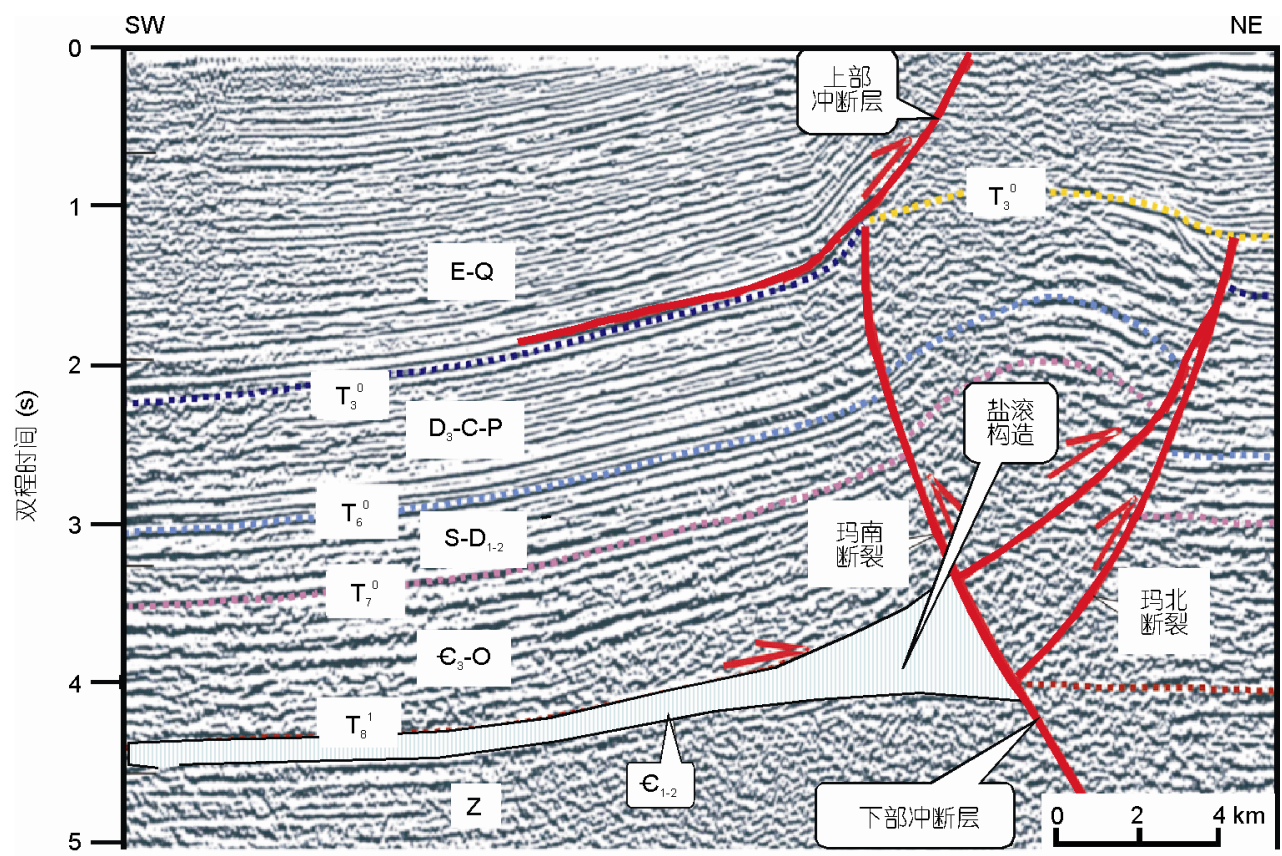

图 4 盐滚构造

据 MZ94-228 地震剖面解释, 剖面位置见图 1-d 
构造之下, 平缓的背斜可以形成良好的油气圈闭，盐 岩层系本身作为盖层，具有良好的封盖性能.

\section{3 盐(上)背斜构造}

中、下寒武统盐枕构造之上的地层, 受盐岩层系 局部聚集形成枕状构造的影响, 发生褶皱形成盐上 层背斜构造. 盐上背斜构造的成因与盐枕构造的形
成密切相关，盐上背斜构造的形态与盐枕构造十分 相似，形成时代也与盐枕构造同期(图 5)。盐上背斜 也是一种有利的圈闭构造，其闭合面积和闭合幅度 受控于盐枕构造的规模.

\section{4 盐拱-盐上断块构造组合}

如图 6 所示, 中、下寒武统盐岩层系在断夹块之

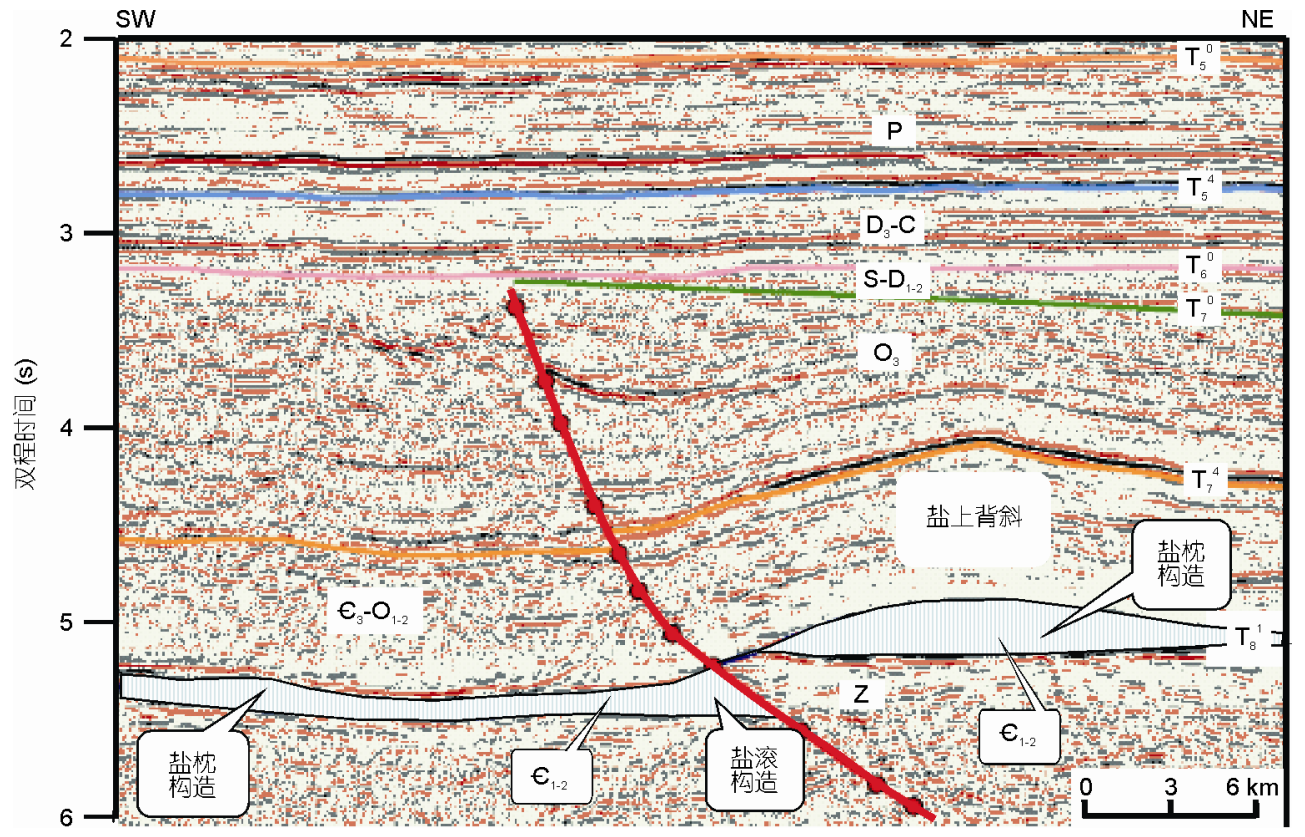

图 5 盐枕构造和盐(上)背斜

据 TZ07-452.8SN 地震剖面解释, 剖面位置见图 1-g

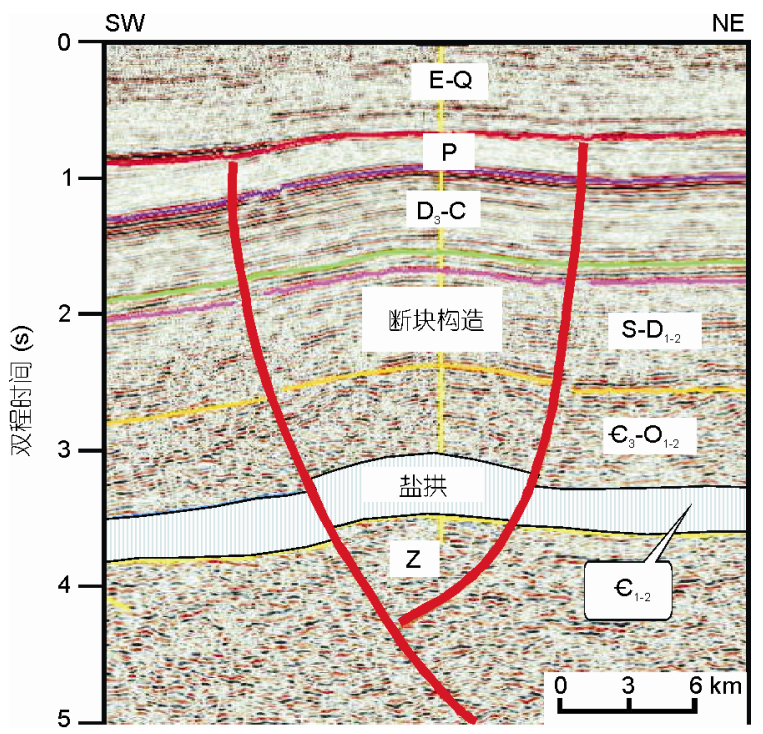

图 6 盐拱-盐上断块构造组合

据 BC07-SN168 地震剖面解释，剖面位置见图 1-b
间聚集增厚形成盐拱构造，断夹块外侧的盐层厚度 小于断块内部. 盐上地层受盐岩拱起的影响, 形成 盐上断块或断褶构造，盐上构造的规模由深层往浅 层逐渐增大. 盐下地层也形成断块构造，但其规模 小于盐拱构造，盐上、盐下都可以形成良好的圈闭 构造，其中盐下构造有盐岩做为盖层，具有良好的 保存条件.

\section{5 基底断裂-盐背斜构造组合}

基底断裂-盐背斜构造组合一般受深部基底断裂 带控制，在基底断裂带上盘，盐岩层系发生流动聚集， 形成盐背斜构造. 盐上地层发生断裂作用，断层一般 不切穿盐岩层系进入基底，而是在盐岩层系顶面或 盐岩层系内部发生滑脱，最终消失在滑脱层中. 滑脱 断层往上扩展，可以形成断层相关褶皱或花状构造 (图 7). 


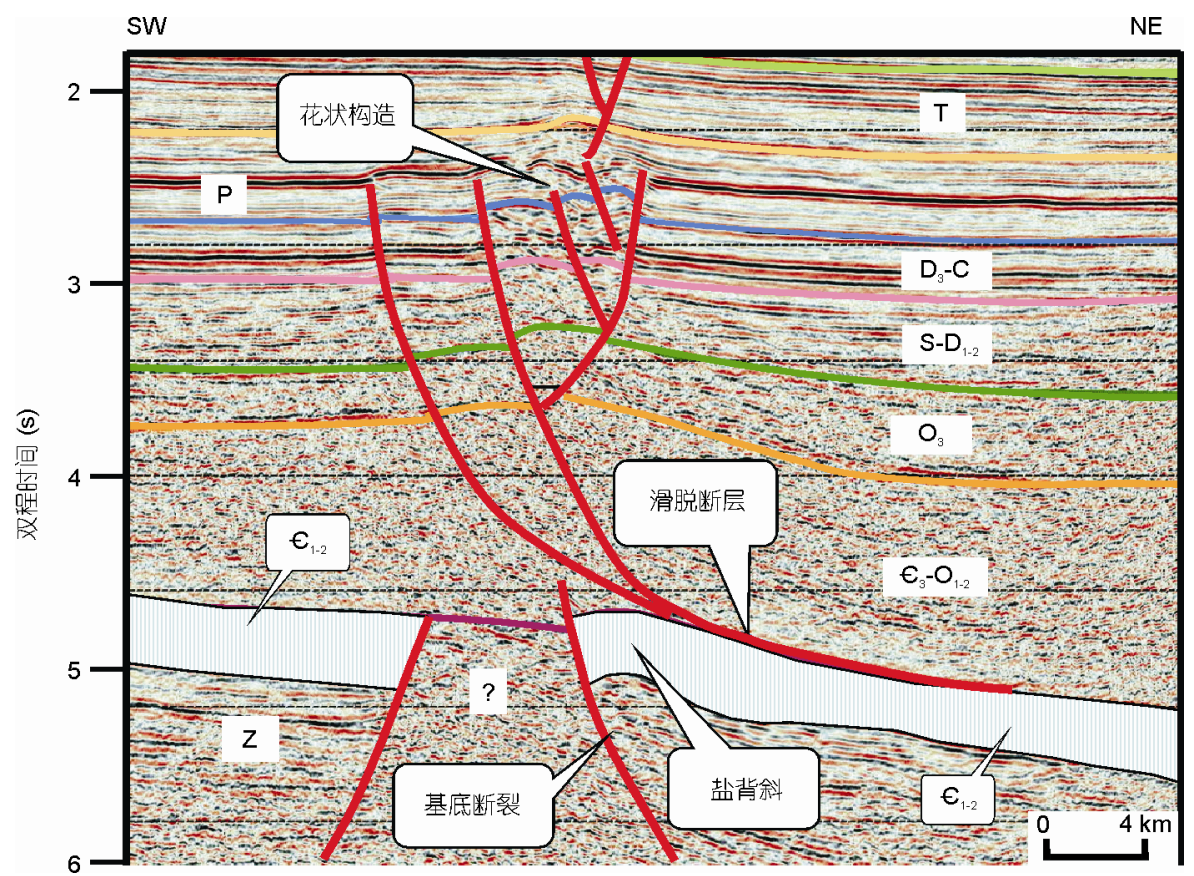

图 7 基底断裂-盐背斜构造组合

据 TZ07-434.9SN 地震剖面解释, 剖面位置见图 1-f

\section{6 基底断块-盐丘构造组合}

在塔里木中央隆起带中西段及邻区, 受基底断 裂控制, 常形成前震旦系基底和震旦系断块构造. 在 基底断块构造之上, 往往有中、下寒武统盐岩层系流 动聚集, 形成盐丘构造. 盐丘构造之上发育盐上背斜 构造, 盐下、盐层和盐上多层次盐相关构造相互叠置, 构成复杂的构造变形图案(图 8).

\section{7 盐岩滑脱-断层相关褶皱组合}

如 HTH-206.2EW 地震剖面所示, 中、下寒武统 盐岩层系流动变形比较明显, 在盐岩滑脱带内形成 一些小规模盐拱构造, 幅度不大. 盐上层系发生断裂 作用, 断层往下进入盐岩层系发生滑脱作用, 断距逐 渐消失在盐岩滑脱带中; 断层往上扩展, 可以形成一 系列断层相关褶皱(图 9).

\section{8 基底断块-盐拱-盐上叠瓦冲断组合}

如 MGT09-112EW 地震剖面所示, 前震旦系基 底形成一系列断块构造, 在断块之上盐体流动发生 局部聚集, 形成盐拱构造, 盐上地层出现一系列断裂 构造, 断层往深层在盐拱部位沿盐岩滑脱层发生滑 脱作用, 往上形成叠瓦状冲断块体. 叠瓦冲断块体主
体由上寒武统和奥陶系构成, 是加里东中期运动的 产物. 志留系至中泥盆统往叠瓦冲断块体的高部位 超覆，上泥盆统和石炭系不整合覆盖在下伏地层之 上，与下伏冲断块体构成典型的潜山-披覆构造组合 (图 10).

\section{3 塔里木盆地中央隆起带中、西段寒武系盐 构造变形机理}

塔里木盆地中央隆起带中、西段及邻区深层寒武 系盐相关构造变形受基底断裂作用、挤压缩短作用、 塑性流动作用、上覆层系重力作用和断裂滑脱作用等 多重因素控制(图 11).

\section{1 基底断裂作用}

航磁和地震资料揭示, 塔里木盆地中央隆起带 中、西段及邻区基底断裂比较发育，基底断裂往上扩 展进入盐岩层系, 可能导致在盐岩层系中发生应力 集中或形成虚脱空间，在差异应力作用下，盐岩层往 基底断裂顶部流动聚集，从而形成盐拱构造. 地震剖 面解释和钻井资料揭示，几乎所有的盐相关构造，如 同岗构造(同 1 井)、卡北构造(方 1 井)、和 4 号断背 


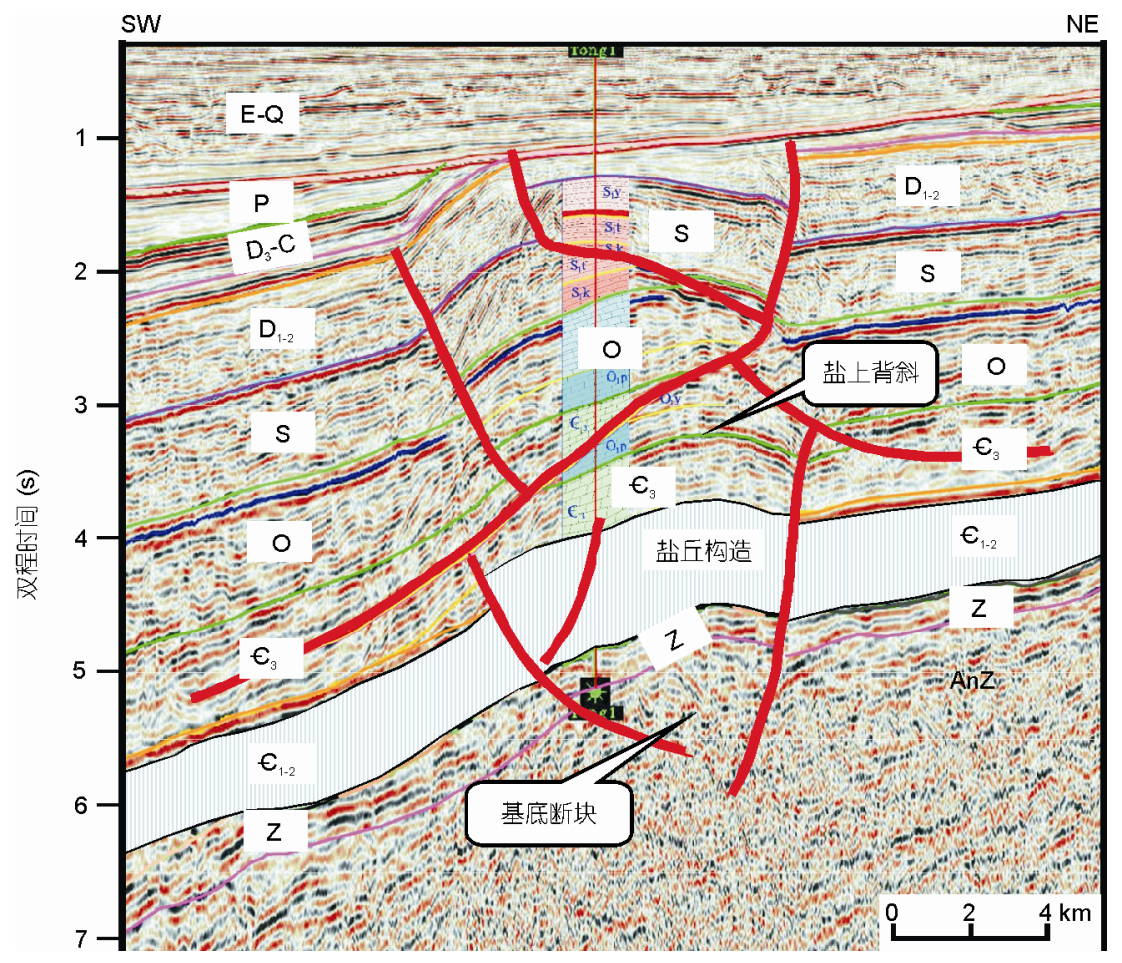

图 8 基底断块-盐丘构造组合

据 BC94-NE157 地震剖面解释, 剖面位置见图 1-a

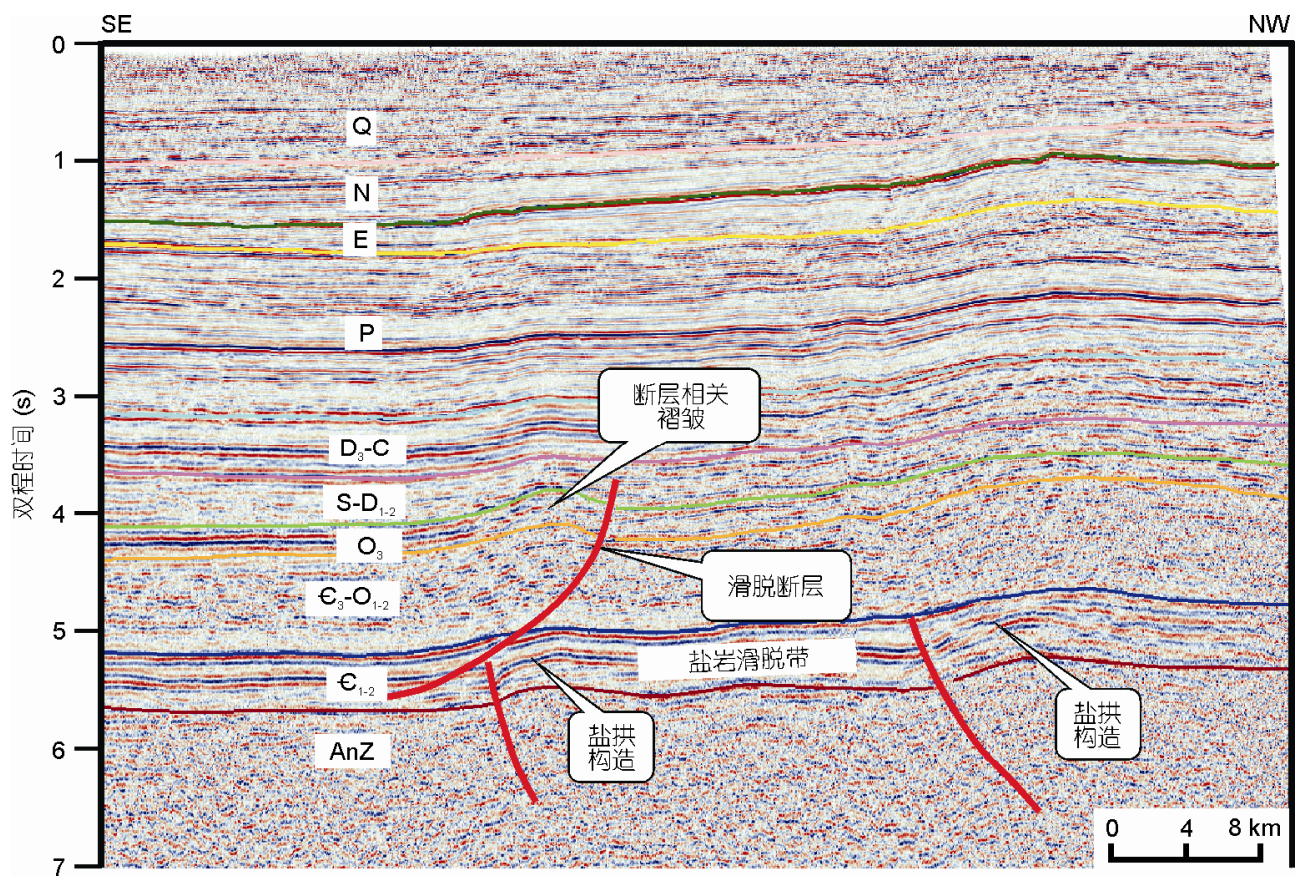

图 9 盐岩滑脱-断层相关褶皱组合

据 HTH-206.2EW 地震剖面解释, 剖面位置见图 1-c 


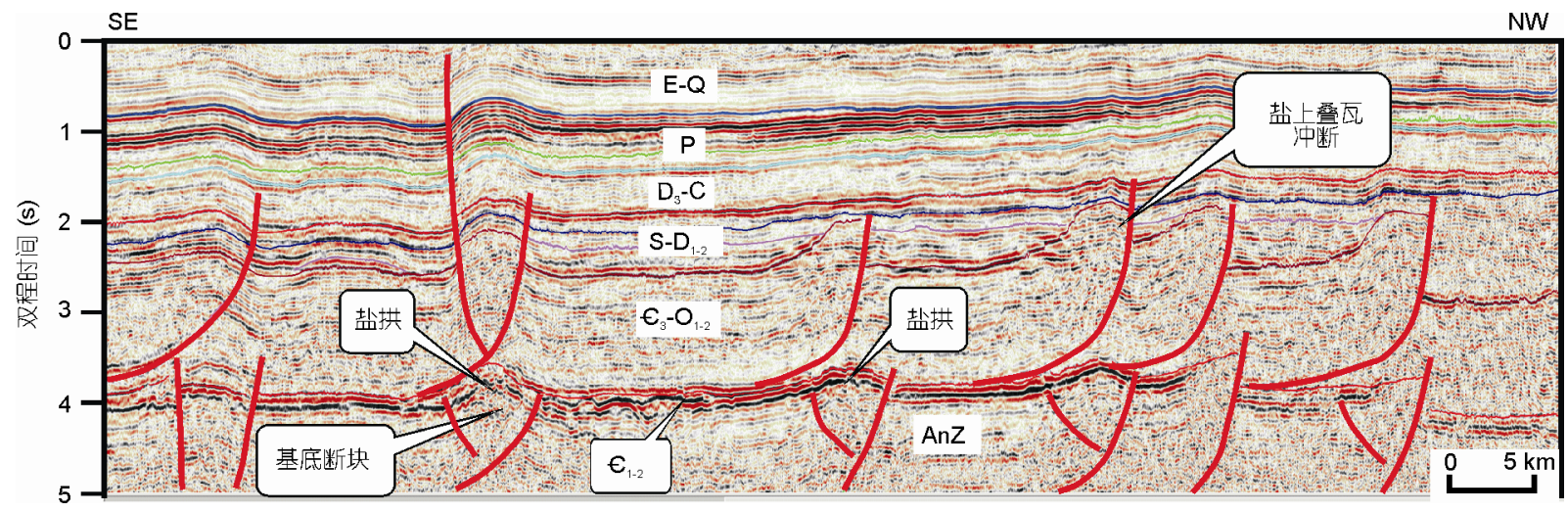

图 10 基底断块-盐拱-盐上叠瓦冲断组合 据 MGT09-112EW 地震剖面解释, 剖面位置见图 1-e

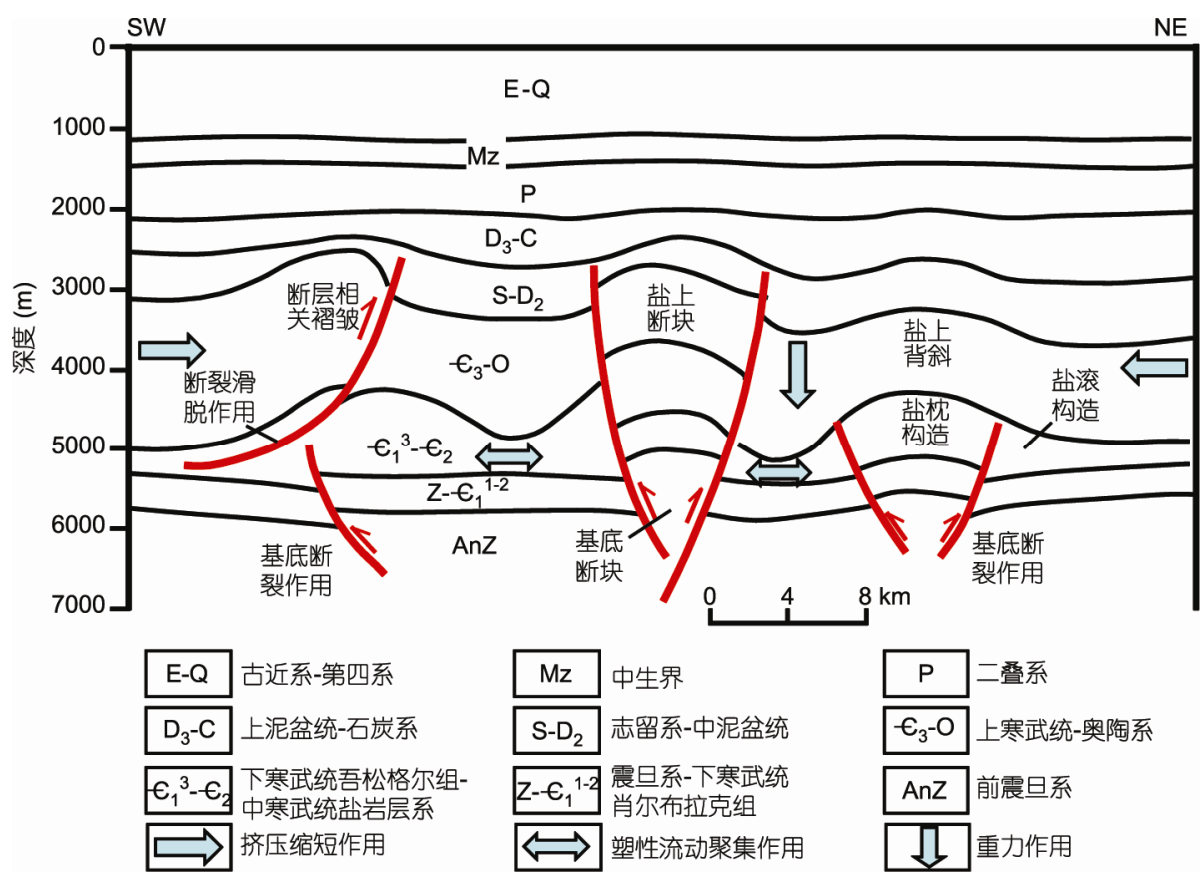

图 11 塔里木盆地中央隆起带中、西段盐相关构造成因模式图

斜(和 4 井)以及海米东构造 (巴探 5 井)等, 可能都与盐 下先存基底断裂带的活动有关. 在盐相关构造形成 时期, 这些先存基底断裂带可以往上进入盐岩层系 或盐上层系. 盐相关构造的分布受到先存基底断裂 的制约，一系列盐相关构造沿基底断层的上盘或基 底断块分布, 具有分排分带分布的特征. 例如, 沿着 康塔库木、海米罗斯、玛扎塔格、卡拉沙依、塔中 2 号和塔中 5 号断裂带分布的盐相关构造. 这就表明, 先存基底断裂带对盐相关构造的形成和分布起着重
要控制作用(图 10,11).

\section{2 挤压缩短作用}

如图 2 所示，塔里木盆地中央隆起带中、西段及 邻区经历多期构造变动, 主要表现为多期强烈挤压、 断裂、褶皱、隆升和剥蚀作用。在塔中隆起, 最重要 的挤压缩短作用发生在加里东中期(图 5,7), 在此后 的多期构造运动中，挤压作用逐渐减弱. 而在巴楚隆 起和麦盖提斜坡，影响盐相关构造形成的强烈挤压 
作用发生在加里东中期和海西早期(图 4, 6, 8 10), 在 海西晚期和喜马拉雅期, 经受了强烈的构造改造和 调整作用(图 4,6，8). 深层中、下寒武统盐岩层系受 挤压缩短作用影响, 发生塑性流动, 形成盐拱或盐背 斜构造. 这种挤压缩短作用也是该区断裂和褶皱构 造形成的主要控制要素, 如前所述, 基底断裂作用与 盐构造形成演化密切相关, 也说明挤压缩短作用对 盐相关构造形成演化具有重要控制作用.

\section{3 塑性流动聚集作用}

塔里木盆地中央隆起带中、西段及邻区深层中、 下寒武统盐岩层系埋藏深度大, 一般埋深超过 5000 $\mathrm{m}$, 具有较高的温度和压力. 深层盐岩层系在较高的 温压条件下，易于发生塑性流动变形，导致形成盐背 斜等盐相关构造. 这种由高温压条件引发的塑性流 动作用, 可能也与区域挤压缩短的触发因素有关.

\section{4 上覆层系的重力作用}

塔里木盆地中央隆起带中、西段及邻区深层中、 下寒武统盐岩层系本身厚度不大, 但上覆有巨厚的 盖层, 盐岩层系受上覆巨厚盖层的差异重力作用控 制, 不同深埋条件下的盐岩层系, 可以发生重力滑动 或重力扩展作用, 形成盐背斜构造等.

\section{5 盐上层断裂滑脱作用}

盐上地层发生断裂作用, 断裂往深层遇到中、下 寒武统盐岩层系, 一般不会穿过盐岩层系进入盐下 地层, 而是在盐岩层系中发生滑脱作用, 断距逐渐减 小直至消失. 这种盐上地层发生的断裂滑脱作用, 可 以在盐上层系中形成盐上背斜、断层相关褶皱等盐相
关构造.

\section{4 讨论和结论}

（1）塔里木盆地中央隆起带中、西段及邻区中、 下寒武统广泛发育盐岩层系, 对该区古生界构造变 形产生重要影响, 以这套盐岩层系为界, 可以划分为 盐下层、盐层和盐上层三个构造-地层层序, 各构造层序组合可以形成不同的盐相关构造样式.

（2）研究区中、下寒武统盐相关构造变形复杂, 主要包括盐枕构造、盐滚构造、盐(上)背斜构造、盐 刺穿构造、盐拱-盐上断块构造组合、基底断裂-盐背 斜构造组合、基底断块-盐丘构造组合、盐岩滑脱断层相关褶皱组合、基底断块-盐拱-盐上叠瓦冲断组 合等.

（3）塔里木盆地中央隆起带中、西段及邻区中、 下寒武统盐相关构造的形成演化和变形机理主要受 控于基底断裂作用、挤压缩短作用、塑性流动聚集 作用、上覆层系重力作用和盐上层断裂滑脱作用等, 盐相关构造主要沿基底断裂或断块构造带成排成带 分布.

(4) 研究区深层中、下寒武统盐岩层系, 作为区 域滑脱层对盐上古生界构造变形起着重要控制作用, 形成一系列含油气圈闭构造. 同时, 由于寒武系盐岩 层系提供的优质盖层和封闭条件, 提升了该区盐下 震旦-寒武系目的层系的油气勘探价值. 但由于该区 盐岩层系形成时代老, 埋藏深度大, 厚度分布不均匀, 流动聚集幅度较小, 圈闭识别和落实难度较大, 盐岩 层系和盐相关构造对油气聚集成藏的控制作用有待 进一步深入研究.

致谢论文撰写过程中得到马宗晋院士、贾承造院士、金之钧教授、翟晓先教授和韩革华教授的热情指导和帮助. 中 石化西北油田分公司在基础地质资料方面给予大力支持. 审稿专家提出宝贵修改意见和建议. 一并致以深切 谢意.

\section{参考文献}

1 刘高波, 施泽进, 余晓宇. 巴楚-麦盖提的区域构造演化与油气分布规律. 成都理工大学学报, 2004, 31: 157-161

2 何治亮, 陈强路, 钱一雄, 等. 塔里木盆地中央隆起区油气勘探方向. 石油与天然气地质, 2006, 27: 769-778

3 李丕龙. 塔里木盆地中央隆起带油气突破领域与勘探方向. 石油与天然气地质, 2007, 28: 576-583

4 焦志峰, 高志前. 塔里木盆地主要古隆起的形成、演化及控油气地质条件分析. 天然气地球科学, 2008, 19: 639-646

5 吕修祥, 杨海军, 白忠凯, 等. 塔里木盆地麦盖提斜坡东段油气勘探前景. 石油实验地质, 2010, 32: 521-526

6 何登发, 周新源, 杨海军, 等. 塔里木盆地克拉通内古隆起的成因机制与构造类型. 地学前缘, 2008, 15: 207-221 
7 肖安成, 杨树锋, 王清华, 等. 塔里木盆地巴楚-柯坪地区南北向断裂系统的空间对应性研究. 地质科学, 2002, 37(增刊): 64-72

8 肖安成, 杨树锋, 李曰俊, 等. 塔里木盆地巴楚隆起断裂系统主要形成时代的新认识. 地质科学, 2005, 40: 291-302

9 余一欣, 黄太柱, 汤良杰, 等. 塔里木盆地塔中低凸起内部构造变形特征. 现代地质, 2010, 24: 1029-1034

10 何文渊, 李江海, 钱祥麟, 等. 塔里木盆地巴楚断隆中新生代的构造演化. 北京大学学报, 2000, 36: 539-546

11 张振生, 李明杰, 刘社平. 塔中低凸起的形成和演化. 石油勘探与开发, 2002, 29: 28-31

12 李明杰, 郑孟林, 冯朝荣, 等. 塔中低凸起的结构特征及其演化. 西安石油大学学报, 2004, 19: 43-45

13 丁文龙, 林畅松, 漆立新, 等. 塔里木盆地巴楚隆起构造格架及形成演化. 地学前缘, 2008, 15: 242-252

14 李铁军, 间相宾. 塔里木盆地沙雅、卡塔克和巴楚隆起油气成藏主控因素对比与评价. 石油与天然气地质, 2007, 28: 721-730

15 王宏语, 刹太亮, 魏福军, 等. 塔里木盆地巴楚中部地区寒武系盐下构造发育特征. 石油与天然气地质, 2004, 25: 554-558

16 蔡习尧, 李越, 钱一雄, 等. 塔里木板块巴楚隆起区寒武系盐下勘探潜力分析. 地层学杂志, 2010, 34: 283-288

17 余一欣, 黄太柱, 汤良杰, 等. 塔里木盆地塔中隆起盐相关断层. 地质学报, 2011, 85: 179-184

18 Khatun S, Doser D I, Imana E C, et al. Locating faults in the Southern Mesilla Bolson, West Texas and Southern New Mexico, using 3-D modeling of precision gravity data. J Environ Engin Geophys, 2007, 12: 149-161

19 Davison I, Alsop I, Birch P, et al. Geometry and late-stage structural evolution of Central Graben salt diapers, North Sea. Marine Petrol Geol, 2000, 17: 499-522

20 Jackson M P A, Hudec M R, Jennette D C, et al. Evolution of the Cretaceous Astrid thrust belt in the ultradeep-water Lower Congo Basin, Gabon. AAPG Bull, 2008, 92: 487-511

21 Koyi H A, Ghasemi A, Hessami K, et al. The mechanical relationship between strike-slip faults and salt diapirs in the Zagros fold-thrust belt. J Geol Soc, 2008, 165: 1031-1044

22 汤良杰, 贾承造, 皮学军, 等. 库车前陆褶皱带盐相关构造样式. 中国科学 D 辑: 地球科学, 2003, 33: 38-46

23 Chen S P, Tang L J, Jin Z J, et al. Thrust and fold tectonics and the role of evaporite in deformation in the western Kuqa foreland of Tarim Basin, northwest China. Mar Petrol Geol, 2004, 21: 1027-1042

24 余一欣，周心怀，汤良杰，等. 渤海海域莱州湾凹陷 KL11-2 地区盐构造特征. 地质学报, 2008, 82: 13-19

25 于建国, 李三忠, 王金铎, 等. 东营凹陷盐底辟作用与中央隆起带断裂构造成因. 地质科学, 2005, 40: 55-68

26 汤良杰, 郭肜楼, 余一欣, 等. 四川盆地东北部前陆褟皱-冲断带盐相关构造. 地质学报, 2007, 81: 1048-1056

27 汤良杰, 杨克明, 金文正, 等. 龙门山冲断带多层次滑脱带与滑脱构造变形. 中国科学 D 辑: 地球科学, 2008, 38(增刊 I ): 30-40

28 杨长清. 江陵凹陷盐构造及与油气聚集的关系. 断块油气田, 2004, 11: 4-6

29 唐文旭, 陈风玲, 范传军. 潜江凹陷王场盐构造的油气成藏特征. 资源环境与工程, 2007, 21: 385-387

30 汤良杰, 李京昌, 余一欣, 等. 库车前陆褶皱-冲断带盐构造差异变形和分段性特征探讨. 地质学报, 2006, 80: 313-320

31 Yu Y X, Tang L J, Yang W J, et al. Thick-skinned contractional salt structures in the Kuqa depression, the northern Tarim Basin: constraints from physical experiments (in Chinese). Acta Geol Sin, 2008, 82: 327-333

32 邬光辉, 王招明, 刘玉魁, 等. 塔里木盆地库车坳陷盐构造运动学特征. 地质论评, 2004, 50: 476-483

33 雷刚林, 谢会文, 张敬洲, 等. 库车坳陷克拉苏构造带构造特征及天然气勘探. 石油与天然气地质, 2007, 28: 816-820

34 汤良杰, 余一欣, 杨文静, 等. 库车坳陷古隆起与盐构造特征及控油气作用. 地质学报, 2007, 81: 145-150

35 汪新, 王招明, 谢会文, 等.塔里木库车㘬陷新生代盐构造解析及其变形模拟. 中国科学: 地球科学, 2010, 40: 1655-1668 